\title{
PELAKSANAAN PROGRAM ADIWIYATA SEBAGAI UPAYA PEMBENTUKAN KARAKTER PEDULI LINGKUNGAN SISWA DI MADRASAH IBTIDAIYAH
}

\author{
Oleh: \\ Ummi Nur Rokhmah \\ Program studi PGMI, Fakultas Tarbiyah dan Keguruan, \\ IAIN Syekh Nurjati Cirebon. \\ Email: umminurrokhmah@syekhnurjati.ac.id
}

\begin{abstract}
Abstrak
Pendidikan lingkungan hidup sangat berperan penting dalam memberikan pemahaman dan pembentukan karakter peduli lingkungan siswa di sekolah.Dalam upaya mempercepat pengembangan pendidikan lingkungan hidup khususnya jalur pendidikan formal untuk mendorong terciptanya pengetahuan dan kesadaran warga sekolah dalam upaya pelestarian lingkungan hidup maka dicanangkan program Adiwiyata. Tujuan penelitian ini adalah Mendeskripsikan pelaksanaan program Adiwiyata sebagai upaya pembentuk karakter peduli lingkungan siswa di MIN Tegalasri Wlingi Blitar.Penelitian ini menggunakan pendekatan kualitatif dengan jenis penelitian deskriptif. Penelitian dilakukan di MIN Tegalasri Wlingi Blitar dengan subjek penelitiannya adalah kepala sekolah, koordinator program Adiwiyata, guru, siswa, petugas kebersihan, penjaga kantin dan para orang tua siswa. Data dikumpulkan melalui teknik wawancara, observasi, dokumentasi, kebijakan berwawasan lingkungan, pelaksanaan kurikulum berbasis lingkungan, kegiatan lingkungan berbasis partisipatif, dan pengelolaan sarana prasarana pendukung ramah lingkungan. Hasil penelitian ini merupakan implementasi dari program Adiwiyata untuk membentuk karakter kesadaran lingkungan pada siswa di MIN Tegalasri Wlingi Blitar. Kata Kunci: Adiwiyata, Karakter, Lingkungan, Peduli, Program.
\end{abstract}


Ummi Nur Rokhmah: Pelaksanaan Program Adiwiyata Sebagai Upaya Pembentukan Karakter Peduli Lingkungan Siswa di Madrasah Ibtidaiyah

\begin{abstract}
Education Environmental is very important in providing an understanding and caring character formation of students in the school environment. In an effort to accelerate the development of environmental education, especially formal education to promote the creation of knowledge and awareness of the school community in environmental protection has been proclaimed Adiwiyata program. The purpose of this study is describe implementation of Adiwiyata Program for Shaping Character Environmental Care Students at MIN Tegalasri Wlingi Blitar. This study used a qualitative approach with descriptive research. The study was conducted in MIN Tegalasri Wlingi Blitar with the subject of his research is the principal, program coordinator Adiwiyata, teachers, students, janitor, cafeteria guards and parents. Data were collected through interview, observation, and documentation. To obtain the validity of data used triangulation techniques and triangulation of sources.The study results were implementation of the program Adiwiyata to shaping the character of the student environmental awareness in MIN Tegalasri Wlingi Blitar is based on four components of the program Adiwiyata namely environmental insightfull policy, implementation of curriculum based on environment, environmental activities based on participatory, management of environmentally friendly supporting facilities and infrastructures.
\end{abstract}

Keywords: Adiwiyata, Care, Character, Environmental, Program.

\title{
A. Pendahuluan
}

Saat ini semakin banyaknya masalah lingkungan hidup di Indonesia khususnya antara lain adalah penebangan hutan secara liar/pembalakan hutan, polusi air dari limbah industri dan pertambangan, polusi udara di daerah perkotaan, asap dan kabut dari kebakaran hutan, kebakaran hutan permanen/tidak dipadamkan, perburuan liar, perambahan suaka alam/suaka margasatwa, penghancuran terumbu karang, pembasmian hewan liar yang dilindungu, pembuangan sampah B3/radioaktif dari negara maju, pembuangan sampah tanpa pemisahan/pengolajan dan hujan asam yang merupakan akibat polusi udara. Kerusakan pada lingkungan hidup terjadi karena dua faktor baik faktor alami ataupun karena ulah atau aktivitas manusia. Namun Pada 
Ummi Nur Rokhmah: Pelaksanaan Program Adiwiyata Sebagai Upaya Pembentukan Karakter Peduli Lingkungan Siswa di Madrasah Ibtidaiyah

kenyataannya saat ini kerusakan lingkungan hidup sebagian besar disebabkan karena ulah manusia itu sendiri. ${ }^{1}$

Oleh karena sikap dan mental manusia yang merusak alam belum berubah, maka kerusakan alam akan terus berlangsung. Untuk mengatasi dampak kerusakan lingkungan diperlukan suatu perubahan sikap dan perilaku yang peduli lingkungan. Kepedulian lingkungan akan berdampak pada program pembangunan yang peduli akan kemanfaatan alam secara berkelanjutan, tidak hanya untuk kepentingan saat ini saja, melainkan juga untuk kepentingan generasi yang akan datang. ${ }^{2}$ Untuk mengendalikan lingkungan agar tetap terjaga sebagai mana mestinya maka diperlukan pendidikan kepada setiap individu agar bisa menjaga ekosistem dan kesetabilan lingkungannya. Pendidikan sangat berperan penting dalam memberikan pemahaman dan pembentukan karakter siswa di sekolah. Pendidikan karakter merupakan langkah penting dan strategis dalam membangun kembali jati diri individu maupun bangsa. ${ }^{3}$

Membangun karakter peduli lingkungan dalam diri seseorang tidak semudah membalikkan telapak tangan.Karakter Peduli Lingkungan adalah sikap dan tindakan yang selalu berupaya mencegah kerusakan pada lingkungan alam di sekitarnya dan mengembangkan upaya-upaya untuk memperbaiki kerusakan alam yang sudah terjadi. ${ }^{4}$

Perilaku peduli lingkungan pada siswa sekolah dasar dapat dilihat dari indikator nilai karakter peduli lingkungan pada siswa sekolah dasar. Indikator nilai karakter peduli lingkungan kelas 1, 2, dan 3 adalah membuang air kecil

${ }^{1}$ Daryanto, \& Suprihatin, A. Pengantar Pendidikan Lingkungan Hidup. Cet. I. (Yogyakarta: Gava Media, 2013)

${ }^{2}$ Priyanto, Y., Djati, M., Soemarno, \& Fanan, Z. Pendidikan Berperspektif Lingkungan Menuju Pembangunan Berkelanjutan. (Jurnal Sosial dan Humaniora, 16(1) , 2013) h. 41-51.

3 Agus Setiawan, Prinsip Pendidikan Karakter dalam Islam (Studi Komparasi Pemikiran al-Ghazali dan Burhanuddin al-Zarnuji), Dinamika Ilmu, 14 (1), 2014.

${ }^{4}$ Aqib, Zainal. Pendidikan Karakter di Sekolah:Membangun Karakter dan Kepribadian Anak, Cet. I. (Bandung : Yrama Widya, 2012) 
Ummi Nur Rokhmah: Pelaksanaan Program Adiwiyata Sebagai Upaya Pembentukan Karakter Peduli Lingkungan Siswa di Madrasah Ibtidaiyah

dan besar di toilet, ikut membersihkan halaman madrasah, membuang sampah pada tempatnya, ikut merawat taman dengan tidak memetik bunga dan tidak menginjak rumput taman, serta ikutmenjaga kebersihan rumah. Sedangkan indikator nilai karakter peduli lingkungan siswa kelas 4, 5 dan 6 sekolah dasar adalah ikut membersihkan lingkungan sekolah, ikut membersihkan toilet, ikut membersihkan tempat sampah, ikut memelihara taman, ikut memperindah kelas dan sekolah dengan tanaman, serta ikut dalam kegiatan menjaga kebersihan lingkungan. ${ }^{5}$

Pendidikan lingkungan hidup menjadi implementasi dari bentuk kepedulian terhadap lingkungan sebagai manifestasi rasa syukur atas karunia yang diberikan Allah SWT melalui alam semesta sehingga pembelajaran menjadi lebih bermakna. Siswa akan diperkenalkan dengan konsep yang menyatu dengan alam itu sendiri. Pendekatan pembelajaran lingkungan pada intinya adalah mendekatkan anak pada kekuasaan Sang Pencipta. ${ }^{6}$

Pendidikan lingkungan tidak akan mengubah situasi dan kondisi lingkungan yang rusak menjadi baik dalam waktu yang singkat, melainkan membutuhkan waktu, proses, dan sumber daya. Atas dasar itulah pendidikan lingkungan sedini mungkin perlu diupayakan agar dapat meminimalisasi kerusakan-kerusakan lingkungan. ${ }^{7}$

Dalam upaya mempercepat pengembangan pendidikan lingkungan hidup khususnya jalur pendidikan formal pada jenjang pendidikan dasar dan menengah dan untuk mendorong terciptanya pengetahuan dan kesadaran warga

${ }^{5}$ Badan Penelitian dan Pengembangan Pusat Kurikulum. Bahan Pelatihan: Penguatan Metodologi Pembelajaran Berdasarkan Nilai-Nilai Budaya Untuk Membentuk Daya Saing Dan Karakter Bangsa. (Jakarta: Kementrian Pendidikan Nasional, 2010).

${ }^{6}$ Muslih, Masnur. Karakter Menjawab Tantangan Krisis Multidimensional. Cet. I. (Jakarta: Bumi Aksara, 2011).

${ }^{7}$ Adam, Ahmad Fajarisma Budi. Analisis Implementasi Kebijakan Kurikulum Berbasis Lingkungan Hidup Pada Program Adiwiyata Mandiri di SDN Dinoyo 2 Malang. (Jurnal Kebijakan dan Pengembangan Pendidikan, 2(2), 2014), h. 166-173. 
Ummi Nur Rokhmah: Pelaksanaan Program Adiwiyata Sebagai Upaya Pembentukan Karakter Peduli Lingkungan Siswa di Madrasah Ibtidaiyah

sekolah dalam upaya pelestarian lingkungan hidup maka pada tanggal 21 Februari 2006 telah dicanangkan program Adiwiyata. ${ }^{8}$

Kata Adiwiyata berasal dari kata Sansekerta.Adi bermakna besar,agung, baik, sempurna.Wiyata bermakna tempat dimana seseorang mendapat ilmu pengetahuan, norma. Jadi, Adiwiyata bermakna tempat yang baik dan ideal dimana diperoleh ilmu pengetahuan, norma serta etika yang dapat menjadi dasar manusia menuju terciptanya kesejahteraan hidup dan cita-cita pembangunan berkelanjutanProgram Adiwiyata adalah salah satu program Kementerian Lingkungan Hidup yang merupakan implementasi Permen Lingkungan Hidup No. 02 th 2009. ${ }^{9}$

Program sekolah Adiwiyata bertujuan untuk menanamkan kecintaan warga sekolah pada lingkungan hidupnya, termasuk menanamkan sikap dan perilaku yang peduli dan berbudaya lingkungan. ${ }^{10}$ Penerapan Program Adiwiyata di setiap sekolah menjadi sebuah tantangan bagi Pemerintah Daerah dalam rangka mengajak dan mensupport setiap sekolah agar bisa mengikuti Program Adiwiyata. Pada dasarnya untuk mencapai suatu tujuan bersama tidak terlepas dari peran stakeholder terkait. ${ }^{11}$

Selain diharapkan dapat mewujudkan lingkungan sekolah sehat, bersih, indah dan nyaman, sehingga dapat membentuk warga sekolah yang peduli dan berbudaya lingkungan, sekolah Adiwiyata juga diharapkan dapat menjadi agen perubahan bagi masyarakat di sekitar sekolah.Sekolah harus

${ }^{8}$ Tim Teknis Kementrian Lingkungan Hidup RI. Panduan Singkat menjadi Sekolah Adiwiyata. (Jakarta: Kementrian Lingkungan Hidup RI, 2012).

9 Tim Adiwiyata Tingkat Nasional. Paduan Adiwiyata Sekolah Peduli dan Berbudaya Lingkungan. (Jakarta: Kerjasama Kementrian Lingkungan Hidup dan Kementrian Kebudayaan dan Pendidikan, 2011).

${ }^{10}$ Widiyaningrum, P., Lisdiyana, \& E. Purwantoyo. Evaluasi Partisipasi Siswa dalam Pengelolaan Sampah untuk Mendukung Program Sekolah Adiwiyata. (Indonesian Journal of Conservation, 4(1), 2015), hal 74-82.

11 Syoffnelli, Zulfan Saam, and Thamrin. Pengaruh Program Adiwiyata Terhadap Pengetahuan Perilaku dan Keterampilan Siswa dan Guru dalam Mengelola Lingkungan pada SMK di Kabupaten Pelalawan. (Jurnal Dinamika Lingkungan Indonesia, 3(1), 2016), h. 16-23.

Al Qalam: Jurnal Ilmiah Keagamaan dan Kemasyarakatan Vol. 13, No. 1, Januari-Juni 2019 
Ummi Nur Rokhmah: Pelaksanaan Program Adiwiyata Sebagai Upaya Pembentukan Karakter Peduli Lingkungan Siswa di Madrasah Ibtidaiyah

menjadi model bagi masyarakat dalam mewujudkan lingkungan yang sehat, bersih, indah dan nyaman.Sikap peduli dan berbudaya lingkungan dari warga sekolah diharapkan dapat ditularkan/berimbas kepada masyarakat sekitar sekolah, guna mewujudkan masyarakat yang berkarakter peduli lingkungan. ${ }^{12}$

Pada awalnya program Adiwiyata hanya dilaksanakan di 10 sekolah di Pulau Jawa sebagai sekolah model dengan melibatkan perguruan tinggi dan LSM yang bergerak di bidang Pendidikan lingkungan hidup. ${ }^{13}$ Namun saat ini sudah banyak sekolah yang menerapkan program Adiwiyata sebagai upaya membentuk karakter peduli lingkungan pada siswa diantaranya adalah MIN Tegalasri Wlingi Blitar. MIN Tegalasri Wlingi mendapat penghargaan Adiwiyata Nasional pada tahun 2013.

Bertolak dari permasalahan tersebut, peneliti tertarik untuk melakukan penelitian yang mendalamserta mengkaji secara seksama tentang pelaksanaan program Adiwiyata sebagai upaya pembentukan karakter peduli lingkungan siswa di MIN Tegalasri Wlingi Blitar.

\section{B. Metode Penelitian}

Penelitian ini menggunakan pendekatan kualitatif (qualitative reaserch) dengan jenis penelitian deskriptif (descriptive research).Penelitian dilakukan di MIN Tegalasri Wlingi Blitar dengan subjek penelitiannya adalah kepala MIN Tegalasri Wlingi Blitar, koordinator program Adiwiyata, guru, siswa, petugas kebersihan, penjaga kantin dan orang tua siswa. Data dikumpulkan melalui teknik wawancara, observasi, dan dokumentasi.Langkah analisis data yang digunakan adalah mengumpulkan data, menyajikan data, mereduksi data dan menarik kesimpulan/ verifikasi. Penelitian ini menggunakan triangulasi teknik dan triangulasi sumber untuk memperoleh keabsahan data.

\footnotetext{
12 Desfandi, Mirza. Mewujudkan Masyarakat Berkarakter Peduli Lingkungan melalui Program Adiwiyata. (Jurnal Sosial Didaktika, 2(2), 2015), h. 31-37.

13 Tim Adiwiyata Tingkat Nasional. Paduan Adiwiyata Sekolah Peduli dan Berbudaya Lingkungan...
} 
Ummi Nur Rokhmah: Pelaksanaan Program Adiwiyata Sebagai Upaya Pembentukan Karakter Peduli Lingkungan Siswa di Madrasah Ibtidaiyah

\section{Hasil dan Pembahasan}

\section{Pelaksanaan Program Adiwiyata dalam Membentuk Karakter Peduli Lingkungan Siswa}

Berdasarkan wawancara dengan subjek penelitian, pengamatan di lapangan dan dokumentasi, Pelaksanaan program Adiwiyata di MIN Tegalasri Wlingi Blitar mengacu pada 4 (empat) komponen yaitu, (1) kebijakan berwawasan lingkungan, (2) pelaksanaan kurikulum berbasis lingkungan, (3) kegiatan lingkungan berbasis partisipatif, dan (4) pengelolaan sarana dan prasarana pendukung ramah lingkungan. Pelaksanaan program Adiwiyata di Tegalasri sesuai dengan komponen program Adiwiyata menurut Badan Litbang.

\section{a. Kebijakan berwawasan lingkungan}

MIN Tegalasri Wlingi Blitarmerancang visi, misi dan tujuan madrasah yang memuat kebijakan perlindungan dan pengelolaan lingkungan hidup agar siswa ikut serta mewujudkan perlindungan dan pengelolaan lingkungan hidupsama seperti pada visi misi dan tujuan madrasah.

Visi, Misi dan Tujuan MIN Tegalasri Wlingi Blitar yaitu,

\section{Visi}

Terwujudnya Alumni MIN.Tegalasri yang berakhlaqul Karimah, cerdas, trampil,berbudaya lingkungan, berdasar Assunah.

\section{Misi}

- Meningkatkan pelaksanaan kurikulum Madrasah yang berwawasan lokal, global, nasional, berkarakter, berbasis peduli dan berbudaya lingkungan

- Meningkatkan pembelajaran aktif, kreatif, efektif dan menyenangkan, berkarakter, berbudaya lingkungan 
Ummi Nur Rokhmah: Pelaksanaan Program Adiwiyata Sebagai Upaya Pembentukan Karakter Peduli Lingkungan Siswa di Madrasah Ibtidaiyah

- Meningkatkan lulusan yang cerdas, terampil, berakhlaqul karimah, serta berbudaya lingkungan.

- Meningkatkan SDM yang profesional dan amanah dan peduli lingkungan.

- Meningkatkan sarana dan prasarana yang berkualitas dan ramah lingkungan, lingkungan madrasah yang bersih dan bebas sampah

- Meningkatkan manajemen berbasis madrasah yang terbuka dan akuntabel.

- Meningkatkan optimalisasi pembiayaan operasional madrasah yang efisien

- Meningkatkan penilaian yang adil dan bermakna.

\section{Tujuan}

- Memberikan pelayanan pendidikan berbasis mutu dengan kurikulum yang lengkap, berkarakter dan berbasis peduli dan berbudaya lingkungan

- Memberikan pelayanan pembelajaran yang optimal untuk mengembangkan potensi peserta didik yang islami, berkarakter, berbudaya lingkungan serta berprestasi akademik maupun non akademik.

- Mewujudkan lulusan dengan nilai rata-rata minimal UN/.UAMBN 8,0, terampil melaksanakan sholat 5 waktu, dan dapat membaca Alquran dengan tartil, berkarakter serta peduli berbudaya lingkungan.

- Mewujudkan SDM dengan kinerja yang handal, dapat diteladani dalam bersikap dan peduli lingkungan.

- Mewujudkan sarana madrasah yang bersih dan sehat bebas dari sampah, prasarana yang memadai, bermanfaat mengembangkan segala potensi warga madrasah dan ramah lingkungan. 
Ummi Nur Rokhmah: Pelaksanaan Program Adiwiyata Sebagai Upaya Pembentukan Karakter Peduli Lingkungan Siswa di Madrasah Ibtidaiyah

Visi, misi dan tujuan madrasah dipasang di setiap ruang di MIN Tegalasri Wlingi Blitar baik di ruang kepala madrasah, guru dan ruang kelas. Hal tersebut dilakukan agar seluruh warga madrasah khususnya siswa dapat dengan mudah menghafal visi dan misi madrasah, sehingga semakin memantapkan tekad dan semangat siswa untuk mewujudkan visi dan misi madrasah.

Selain membentuk visi, misi dan tujuan madrasah yang memuat kebijakan perlindungan dan pengelolaan lingkungan hidup, MIN Tegalasri Wlingi Blitarjuga membuat kebijakan berupa pengintegrasian pendidikan lingkungan hidup kepada setiap mata pelajaran. Mata pelajaran yang terintegrasi pendidikan lingkungan hidup (PLH) yaitu mata pelajaran agama (Quran Hadist, Fiqih, Akidah Akhlak, Sejarah Kebudayaan Islam dan Bahasa Arab), muatan lokal (Bahasa Jawa dan Bahasa Inggris), dan pembelajaranTematik.Silabus dan RPP dari semua mata pelajarantersebut telah memuat indikator ketuntasan pendidikan lingkungan hidup. Selain mengintegrasikan pada pembelajaran, MIN Tegalasri Wlingi Blitar juga mengintegrasikan PLH pada ekstrakurikuler pramuka dengan cara memasukkan tema lingkungan pada kegiatannya.

Kebijakan berwawasan lingkungan lainnya yaitu membuat peraturan madrasah yang berkaitan dengan lingkungan sebagai upaya membentuk karakter peduli lingkungan siswa. Peraturan dibuat dalam bentuk kata ajakan dan slogan yang di tempel di ruang kelas dan di luar kelas. Peraturan madrasah terkait dengan lingkungan antara lain:

1) Peraturan untuk selalu menjaga kebersihan lingkungan madrasah dengan membuang sampah pada tempat yang telah disediakan dan terpilah menjadi 3 yaitu tempah sampah basah, tempat sampah kering, dan tempat sampah plastik. Bagi siswa yang membuang sampah tidak terpilah, maka akan diberikan sanksi. Sanksi tersebut dinamakan "satu sampah lima pahala". Siswa yang membuang satu sampah tidak pada tempatnya atau tidak dipilah, diminta 
Ummi Nur Rokhmah: Pelaksanaan Program Adiwiyata Sebagai Upaya Pembentukan Karakter Peduli Lingkungan Siswa di Madrasah Ibtidaiyah

mengambil lima sampah di lingkungan sekolah untuk dibuang ke tempat sampah sesuai dengan jenis sampahnya

2) Peraturan untuk selalu menjaga keanekaragaman hayati di madrasah dengan cara merawat tanaman yang ada di madrasah. Bagi siswa yang merusak keanekaragaman hayati madrasah diberikan sanksi berupa mengganti tanaman yang telah dirusak.

3) Peraturan untuk tidak membawa sampah plastik ke madrasah. Apabila peraturan itu dilanggar maka siswa diberikan sanksi berupa membawa bibit atau tanaman dari rumah. Tanaman ditanam di plastik yang dibawa siswa ke madrasah sesuai jenjang kelas. Kelas 1 membawa tanaman cabe, kelas 2 tomat. Kelas 3 tanaman terong, kelas 4 kangkung, kelas 5 sawi. Kelas 6 markisa.

\section{b. Pelaksanaan Kurikulum Berbasis Lingkungan}

Dalam rangka mewujudkan program Adiwiyata sebagai upaya pembentukan karakter peduli lingkungan siswa, guru dalam penyampaian materi yang terintegrasi dengan pendidikan lingkungan hidup menggunakan model pembelajaran PAIKEM (Pembelajaran Aktif, Inovatif, Kreatif, Efektif dan Menyenangkan).Pendekatan yang digunakan adalah pendekatan saintifik denganstrategi pembelajaran Contextual Teaching Learning(CTL). Metode pembelajaran yang sering digunakan adalah ceramah, diskusi, tanya jawab, penugasan, demonstrasi, praktek langsung dan observasi lapangan. Kegiatan pembelajaran mata pelajaran PLH atau mata pelajaran lain yang terintegrasi PLH tidak hanya dilakukan di dalam kelas namun juga di luar kelas agar siswa tidak jenuh dan dapat bersentuhan langsung dengan alam.Guru juga memasukkan isu-isu lokal dan global tentang lingkungan yang sering terjadi, pada materi ajar mata pelajaran PLH dan mata pelajaran lain yang terintegrasi PLH. 


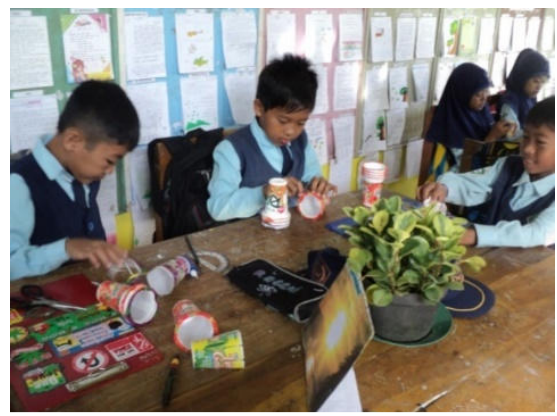

Gambar 1. Pembelajaran Pendidikan lingkungan hidup di dalam kelas

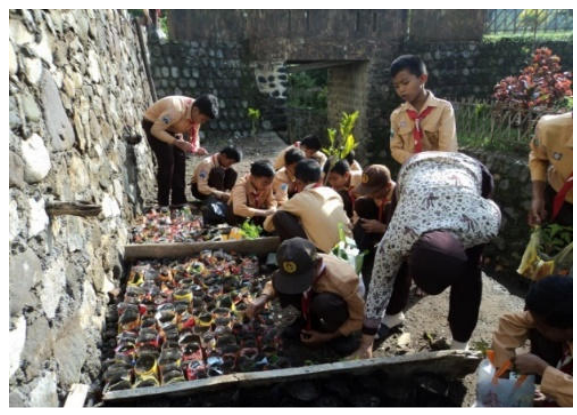

Gambar 2. Pembelajaran Pendidikan lingkungan hidup di luar kelas

Di dalam beberapa kesempatan, guru juga mengajarkan siswa bagaimana cara membuat karya atau inovasi berupa kerajinan tangan yang terbuat dari bahan-bahan bekas maupun karya ilmiah yang bertemakan lingkungan.Pembuatan karya tersebut disesuaikan dengan materi pelajaran. Misal pada pembelajaran bahasa Indonesia dengan materi puisi, siswa diminta untuk membuat puisi dengan tema lingkungan hidup. Hasil inovasi siswa dari pembelajaran diletakkan di dalam kelas dan di lingkungan sekolah agar semua warga sekolah khususnya siswa dapat melihat karyakarya yang telah dibuat.Dalam menilai ketercapaian indikator pada setiap materi yang terintegrasi pendidikan lingkungan hidup, guru melakukanpengamatan terhadap sikap kepedulian siswa terhadap lingkungan baik saat pelajaran berlangsung maupun di luar jam pelajaran dengan cara melihat sikap kepedulian siswa terhadap lingkungan. Dalam mengamati sikap siswa, guru dibantu oleh guru mata pelajaran lain dan siswa. 
Ummi Nur Rokhmah: Pelaksanaan Program Adiwiyata Sebagai Upaya Pembentukan Karakter Peduli Lingkungan Siswa di Madrasah Ibtidaiyah

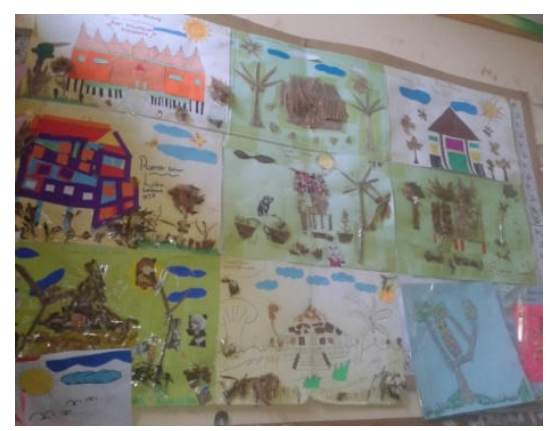

Gambar 3.Inovasi berupa karya ilmiah siswa tentang lingkungan

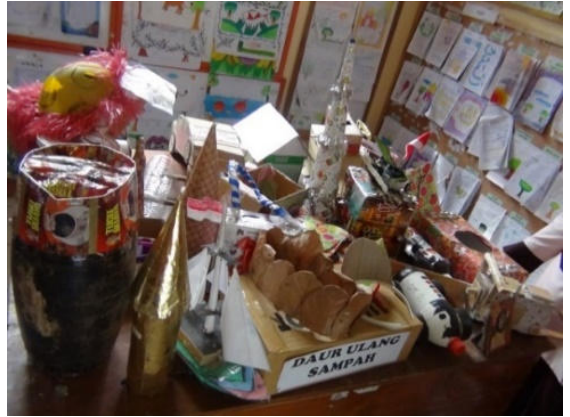

Gambar 4. Inovasi berupa daur ulang sampah

Selain melakukan pembiasaan sikap peduli lingkungan melalui pendidikan lingkungan hidup di setiap mata pelajaran, MIN Tegalasri Wlingi Blitar juga melakukan pembiasaan melalui kegiatan ekstrakulikuler. Ekstrakurikuler yang terkait dengan pengelolaan dan perlindungan adalah ekstrakurikuler farmerclub. Kegiatan dalam Ekstrakurikuler farmerclub berhubungan dengan bercocok tanam mulai dari pembibitan sampai proses panen. Setiap kegiatan ekstrakurikuler siswa dibiasakan untuk merapikan dan membersihkan tempat kegiatan ekstrakurikuler sebelum dan sesudah kegiatan ekstrakurikuler, baik pada ekstrakulikuler farmerclub maupun ekstrakurikuler lainnya.

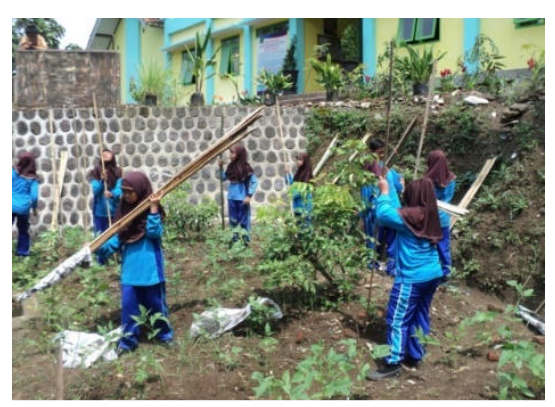

Gambar 5.Kegiatan Farmer Club

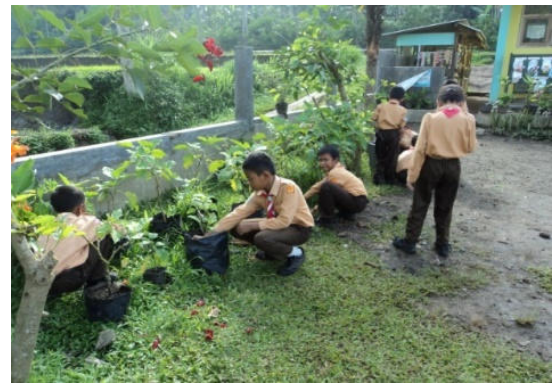

Gambar 6.Kegiatan Farmer Club

Di dalam lingkungan sekolah guru sangat berperan aktif dalam memberikan keteladan sikap peduli terhadap lingkungan.Perawatan lingkungan di sekitar madrasah bukan hanya tanggung jawab siswa saja, 
Ummi Nur Rokhmah: Pelaksanaan Program Adiwiyata Sebagai Upaya Pembentukan Karakter Peduli Lingkungan Siswa di Madrasah Ibtidaiyah

melainkan juga tanggung jawab guru dan seluruh warga sekolah lainnya.Sedangkan ketika siswa di rumah, Madrasah melibatkan secara aktif peran orang tua untuk memberikan keteladanan sikap peduli terhadap lingkungan.Madrasah meminta orang tua memberikan teguran kepada siswa yang melakukan tindakan merusak lingkungan ketika berada di rumah.Selain dilibatkan dalam pemberian keteladanan ketika siswa di rumah, orang tua siswa juga dilibatkan secara aktif dalam penyedian dan perawatan tanaman toga di madrasah.

\section{c. Kegiatan Lingkungan Berbasis Partisipatif}

Kegiatan lingkungan berbasis partisipatif adalah merupakan gerakan kesadaran berbudaya dan peduli lingkungan bagi seluruh warga sekolah. ${ }^{14}$ Dalam rangka melaksanakan kegiatan lingkungan berbasis partisipatif, MIN Tegalasri Wlingi Blitar membentuk 9 kelompok kerja (Pokja) yang beranggotakan guru, siswa dan orang tua siswa. 9 pokjatersebutantara lain pokja hutan pendidikan, pokja tanaman produktif, pokjagreen house, pokja kolam, pokja berburu sampah, pokja prokasih, pokja taman, pokja toga dan pokja pembibitan. Masing-masing pokja beranggotakan siswa dengan dikoordinatori oleh guru kecuali pokja toga yang beranggotakan orang tua siswa. Masing-masing pokja memiliki tanggung jawab untuk memelihara bidang kajiannya.

Kegiatan lingkungan berbasis partisipatif dilakukan rutin setiap hari dan setiap minggu melaluikegiatan rutin harian dan kegiatan rutin mingguan. Kegiatan rutin harian yang dilakukan yaitu piket kelas dan piket menyiram tanaman kelas setiap pagi sesuai jadwal yang telah ditentukan dan kegiatan berburu sampah selama 1 menit sebelum dan sesudah

14 Hidayatullah, F. \& Mudjito. Implementasi Program Adiwiyata Melalui Kegiatan Lingkungan Berbasis Partisipatif di SMP Negeri 1 Pandaan. (Jurnal Inspirasi Manajemen Pendidikan, 5(1), 2017) h. 1-8.

Al Qalam: Jurnal Ilmiah Keagamaan dan Kemasyarakatan Vol. 13, No. 1, Januari-Juni 2019 
Ummi Nur Rokhmah: Pelaksanaan Program Adiwiyata Sebagai Upaya Pembentukan Karakter Peduli Lingkungan Siswa di Madrasah Ibtidaiyah

pembelajaran. Kegiatan rutin mingguan dilaksanakan pada hari jumat yaitu kegiatan jumat beriman (bersih, indah dan nyaman).

Setiap tahun MIN Tegalasri Wlingi Blitar mengadakan kegiatan lingkungan berbasis partisipatifyang disebut dengan hari Aksi. Hari aksi diadakan di lingkungan madrasah maupun di luar madrasah pada hari-hari bertema lingkungan seperti hari sampah, hari air, hari pohon, hari lahan basah dan hari lingkungan hidup. Pada hari sampah, madrasah mengadakan lomba bertema lingkungan, hari sampah. Lomba yang pernah diadakan di MIN Tegalasri Wlingi adalah lomba kebersihan kelas dan lomba mendaur ulang sampah non organik pada hari sampah. Kegiatan yang dilakukan dalam rangka memperingati hari airyaitu siswa yang tergabung menjadi pokja prokasih membersihkan sampah yang ada di aliran sungai dan rumput disekitar pinggiran sungai di lingkungan dan di luar madrasah. Kegiatan yang dilakukan dalam rangka memperingati hari pohon yaitu siswa yang tergabung dalam pokja green house melakukan kegiatan peduli kehati dengan cara memupuk tanaman, membersihkan sampah, rumput dan menyirami green house. Kegiatan dalam rangka memperingati hari lahan basah dan hari lingkungan Hidup yaitu siswa dan warga sekolah lainnya membersihkan lngkungan sekitar madrasah yang melibatkan K3S kecamatan Wlingi dan masyarakat sekitar.

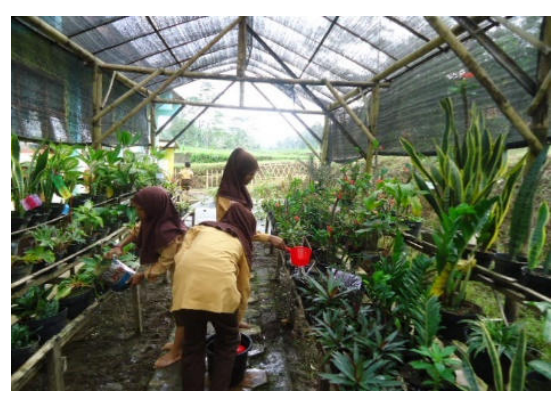

Gambar 7.Siswa yang menjadi anggota pokja green house menyirami green house

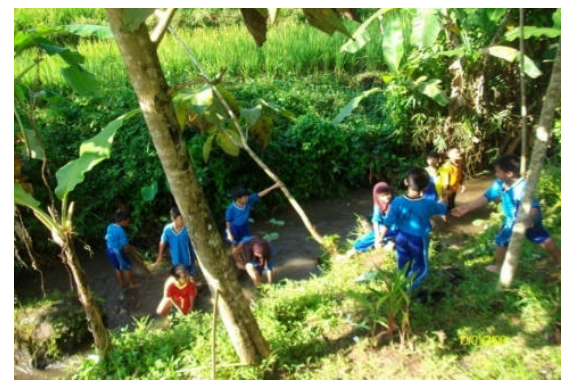

Gambar 8.Siswa yang menjadi anggota pokja kasih Membersihkan kali saat hari Air

Al Qalam: Jurnal Ilmiah Keagamaan dan Kemasyarakatan Vol. 13, No. 1, Januari-Juni 2019 
Ummi Nur Rokhmah: Pelaksanaan Program Adiwiyata Sebagai Upaya Pembentukan Karakter Peduli Lingkungan Siswa di Madrasah Ibtidaiyah

Dalam mewujudkan program Adiwiyata, MIN Tegalasri Wlingi Blitar mendapat dukungan dari berbagai pihak terkait dalam upaya pengelolaan dan perlindungan lingkungan hidup. Beberapa pihak yang mendukung antara lain:

1) Orang tua siswa mendukung dengan menyumbangkan tanaman toga dan membantu merawat tanaman toga di madrasah

2) Kecamatan Wlingi menyumbangkan tanaman hias dan bibit sayuran serta membantu membersihkan lingkungan sekitar jika ada kegiatan lingkungan di madrasah

3) Dinas pertanian kabupaten Blitar menyumbangkan bibit sayuran dan membantu mengajarkan pembuatan pupuk kompos.

4) Puskesmas Wlingi membantu mengelola kantin yang bersih dan sehat.

5) Masyarakat sekitar madrasah membantu membersihkan lingkungan sekitar jika ada kegiatan lingkungan di madrasah.

6) Badan Lingkungan Hidup (BLH) kabupaten Blitar menyumbangkan tempah sampah terpilah

7) Pemulung membantu untuk memungut sampah di madrasah.

\section{d. Pengelolaan sarana prasarana pendukung ramah lingkungan.}

MIN Tegalasri Wlingi Blitar menyediakan sarana prasarana guna mengatasi permasalahan lingkungan di madrasah, sekaligus digunakan sebagai pembelajaran lingkunganhidup kepada siswa. Sarana prasarana yang telah disediakan MIN Tegalasri Wlingi Blitar antara lain:

1) Tempat sampah terpilah menjadi tiga yaitu tempat sampah untuk sampah organik (basah), tempat sampah untuk sampah non organik (kering) selain plastik, sampah non organik (kering) untuk plastik.

2) Tempat pembuangan sampah sementara. Terdapat 2 tempat pembuangan sampah sementara yaitu untuk sampah organik dan sampah non organik. 
Ummi Nur Rokhmah: Pelaksanaan Program Adiwiyata Sebagai Upaya Pembentukan Karakter Peduli Lingkungan Siswa di Madrasah Ibtidaiyah

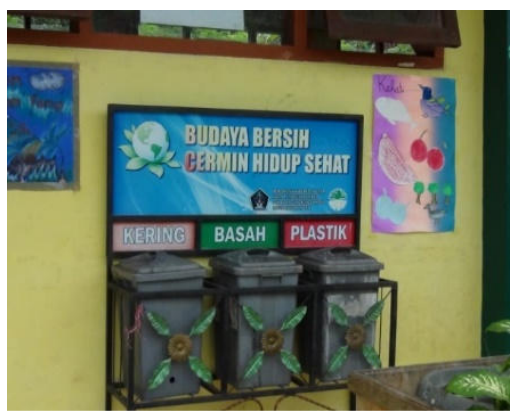

Gambar 9.Tempat pembuangan sampah sementara MIN Tegalasri Wlingi Blitar

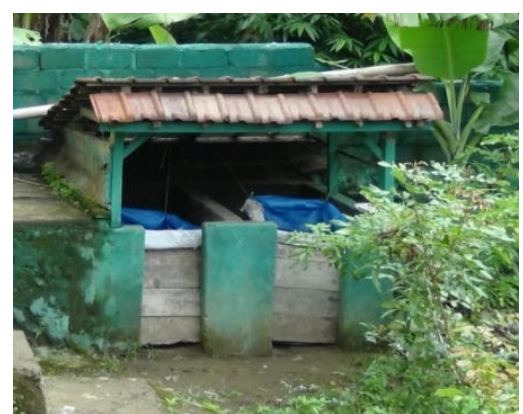

Gambar 10.Tempat pembuangan sampah sementara MIN Tegalasri Wlingi Blitar

3) Tempat cuci tangan/ wastafel di depan masing-masing kelas.

4) Toilet yangdisediakan sebanding dengan jumlah siswa. 4 toilet untuk siswa, 1 toilet untuk guru dan 1 toilet di mushola.

5) Alat penyaringan air sederhana untuk menjernihkan air secara sederhana sekaligus sebagai pembelajaran kepada siswa cara menjernihkan air secara sederhana.

6) Peralatan kebersihan (sapu, kemoceng dan sekrop) untuk membersihkan lingkungan madrasah.

7) Kantin sehat dan ramah lingkungan. Kantin sehat adalah kantinyang menjual makanan bebas $5 \mathrm{P}$ (pengawet, pewarna, pemanis, pengenyal, dan pestisida), sedangkan kantin ramah lingkungan adalah kantin yang mengurangi penggunaan wadah makanan berbahan plastik dan menggantinya dengan kertas minyak.

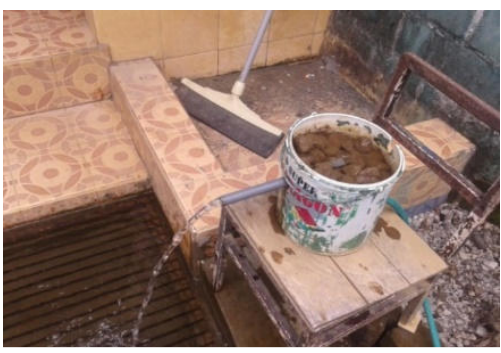

Gambar 11.Alat penyaringan air sederhana MIN Tegalasri Wlingi

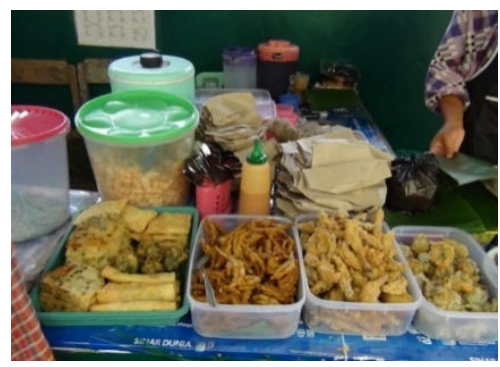

Gambar 12.Kantin madrasah yang sehat dan ramah lingkungan

Al Qalam: Jurnal Ilmiah Keagamaan dan Kemasyarakatan Vol. 13, No. 1, Januari-Juni 2019 
Ummi Nur Rokhmah: Pelaksanaan Program Adiwiyata Sebagai Upaya Pembentukan Karakter Peduli Lingkungan Siswa di Madrasah Ibtidaiyah

8) Taman, green house, hutan madrasah, lahan tanamproduktif dan kolam ikan digunakan sebagai pelestarian sumberdaya alam di madrasah sekaligus sebagai pembelajaran keanekaragaman hayati kepada siswa.

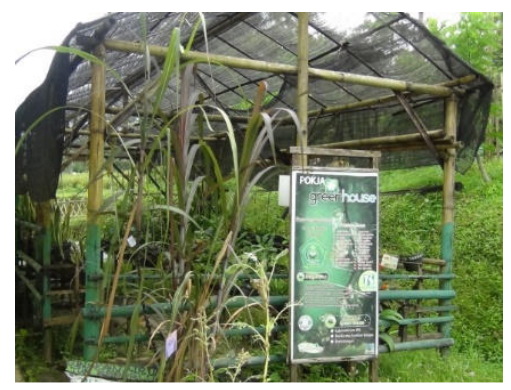

Gambar 13.Green house MIN Tegalasri Wlingi Blitar

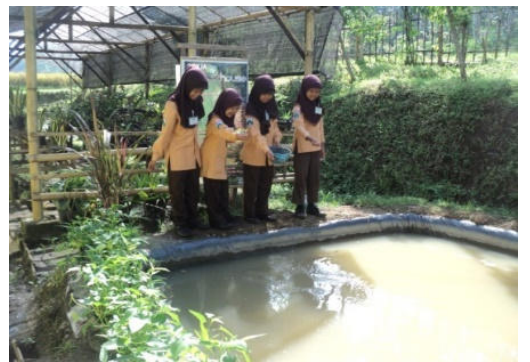

Gambar 14.Kolam ikan MIN Tegalasri Wlingi Blitar

Perawatan terhadap sarana dan prasarana perlu dilakukan secara berkala agar dapat langsung diperbaiki apabila terdapat kerusakan (Barnawi and Arifin 2012).Dalam perawatan sarana prasarana tersebut,MIN Tegalasri Wlingi Blitar melakukan beberapa tindakan, antara lain:

1) Membersihkan tempat sampah di depan kelas jika sudah penuh dan dibuang ke pembuangan sampah sementara sekolah di sesuai jenisnya

2) Membersihkan fasilitas sanitasi sekolah seperti toilet dan wastafel/tempat cuci tangan setiap hari.

3) Melakukan pemantauan terhadap fungsi sumur resapan dan biopori yang ada di sekolah secara berkala yaitu setiap satu minggu sekali.

4) Merawat dan membersihkan taman, green housedan kolam ikan. Untuk merawat taman dan green houseyaitu dengan merawat tanaman seperti menyiram dan membersikan rumput-rumput yang tumbuh, sedangkan untuk merawat kolam ikan yaitu dengan memberi makan ikan di kolam dan membersihkan kolam secara berkala. 
Ummi Nur Rokhmah: Pelaksanaan Program Adiwiyata Sebagai Upaya Pembentukan Karakter Peduli Lingkungan Siswa di Madrasah Ibtidaiyah

5) Melakukan pemantauan secara berkala terhadap kebersihan kantin dan makanan yang dijual di kantin setiap bulan sekali dibantu oleh puskesmas Wlingi.

6) Memanfaatkan listrik, air dan Alat Tulis Kantor (ATK) secara efisien yaitu dengan cara mematikan lampu, kran air, komputer, AC, dan alat elektronik lainnya jika tidak digunakan.

\section{Hambatan dalam Pelaksanaan Program Adiwiyata di MIN Tegalasri} Wlingi Blitar untuk Membentuk Karakter Peduli Lingkungan Siswa

Hambatan dalam pelaksanaan program Adiwiyata untuk membentuk karakter pedulilingkungan siswa di MIN Tegalasri Wlingi Blitar antara lain:

1. Terbatasnya dana dalam pelaksanaan program Adiwiyata, Sedangkan madrasah tidak diperbolehkan mengambil pungutan berupa uang dari orang tua siswa.Dalam mengatasihambatan ini, pihak madrasah meminta bantuan kepada pihak-pihakterkait. Pihak-pihak terkait yang telah memberikan bantuan kepada MIN Tegalasri Wlingi Blitar diantaranya Badan Lingkungan Hidup (BLH) kabupaten Blitar memberikan bantuan berupa pengadaan tempat sampah terpilah, Kecamatan Wlingi memberikan bantuan berupa penyediaan tanaman hias dan bibit tanaman sayur, orang tua siswa memberikan bantuan berupa penyediaan tanaman hias dan tanaman toga, dan Dinas pertanian kabupaten Blitar memberikan ban/tuan berupa penyediaan bibit tanaman sayur.

2. Belum memiliki koperasi yang menjual alat-alat tulis di MIN Tegalasri Wlingi Blitar, sehingga beberapa siswa masih membeli alat-alat tulis di luar sekolah. Hal itu pula yang membuat siswa memiliki kesempatan untuk membeli makanan ringan yang sebagian besar berbungkus plastik, sehingga menambah sampah plastik di madrasah.Selain itu masih ada siswa yang membawa bekal dari rumah yang menggunakan bungkus plastik.Untuk mengatasi hambatan ini pihak madrasah 
Ummi Nur Rokhmah: Pelaksanaan Program Adiwiyata Sebagai Upaya Pembentukan Karakter Peduli Lingkungan Siswa di Madrasah Ibtidaiyah

menerapkan tindakan $3 \mathrm{R}$ (Reduse, Reuse dan Recycle) untuk menanggulangi sampah plastik. Tindakan reduse dengan mengganti penggunaan sampah plastik di kantin sekolah. Tindakan rause dilakukan dengan menggunakan bahan yang terbuat dari plastik secara berulang, seperti menggunakan botol dan minuman untuk pot tanaman. Tindakan recycledilakukan dengan mengubah bahan bekas dari plastik menjadi macam-macam kerajinan tangan. Selain menerapkan tindakan 3R, MIN Tegalasri Wlingi Blitar juga bekerjasama dengan pemulung. Sampah yang masih bagus diberikan kepada pemulung, agar bisa dijual kembali. MIN Tegalasri Wlingi Blitar juga memberikan sanksi kepada siswa yang membawa sampah plastik ke madrasah. Sanksi yang diberikan kepada siswa berupa membawa bibit atau tanaman dari rumah. Tanaman ditanam di plastik yang dibawa siswa ke madrasah sesuai jenjang kelas. Kelas 1 membawa tanaman cabe, kelas 2 tomat. Kelas 3 tanaman terong, kelas 4 kangkung, kelas 5 sawi dan kelas 6 tanaman markisa.

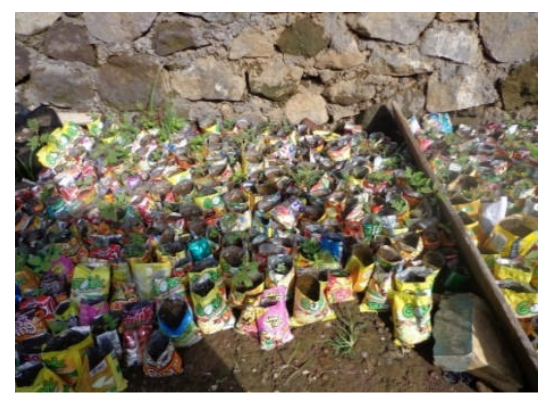

Gambar 17.Sampah plastik untuk pot tanmaan

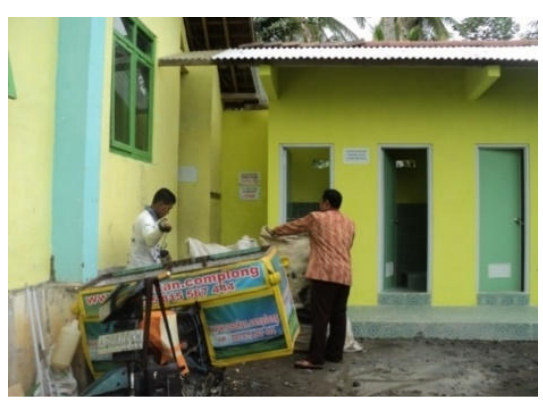

Gambar 18.Pemulung mengambil sampah di MIN Tegalasri Wlingi

\section{Simpulan}

Berdasarkan hasil penelitian yang telah dipaparkan, maka dapat diambil kesimpulan bahwa Pelaksanaan program Adiwiyata dalam membentuk karakter peduli lingkungan siswa di MIN Tegalasri Wlingi Blitar didasarkan pada 4 komponen program Adiwiyata yaitu (1) kebijakan berwawasan lingkungan, (2) 
Ummi Nur Rokhmah: Pelaksanaan Program Adiwiyata Sebagai Upaya Pembentukan Karakter Peduli Lingkungan Siswa di Madrasah Ibtidaiyah

pelaksanaan kurikulum berbasis lingkungan, (3) kegiatan lingkungan berbasis partisipatif, dan (4) pengelolaan sarana dan prasarana pendukung ramah lingkungan. Terdapat beberapa hambatan dalam melaksanakan program Adiwiyata di MIN Tegalasri Wlingi Blitar yaitu (1) Terbatasnya dana dalam pelaksanaan program Adiwiyata, Sedangkan madrasah tidak diperbolehkan mengambil pungutan berupa uang dari orang tua siswa.Dalam mengatasi hambatan ini, pihak madrasah meminta bantuan kepada pihak-pihakterkait untuk membantu pendanaan program Adiwiyata. (2) Belum memiliki koperasi yang menjual alat-alat tulis di MIN Tegalasri Wlingi Blitar, sehingga beberapa siswa masih membeli alat-alat tulis di luar sekolah. Untuk mengatasi hambatan ini pihak madrasah menerapkan tindakan $3 \mathrm{R}$ (Reduse, Reuse dan Recycle), bekerjasama dengan pemulungdan memberikan sanksi kepada siswa yang membawa sampah plastik ke madrasah. 
Ummi Nur Rokhmah: Pelaksanaan Program Adiwiyata Sebagai Upaya Pembentukan Karakter Peduli Lingkungan Siswa di Madrasah Ibtidaiyah

\section{Daftar Pustaka}

Adam, Ahmad Fajarisma Budi. "Analisis Implementasi Kebijakan Kurikulum Berbasis Lingkungan Hidup Pada Program Adiwiyata Mandiri di SDN Dinoyo 2 Malang." Jurnal Kebijakan dan Pengembangan Pendidikan, 2(2), 2014: 166-173.

Aqib, Zainal. Pendidikan Karakter di Sekolah:Membangun Karakter dan Kepribadian Anak, Cet. I . Bandung : Yrama Widya, 2012.

Badan Penelitian dan Pengembangan Pusat Kurikulum. Bahan Pelatihan: Penguatan Metodologi Pembelajaran Berdasarkan Nilai-Nilai Budaya Untuk Membentuk Daya Saing Dan Karakter Bangsa. Jakarta: Kementrian Pendidikan Nasional, 2010.

Barnawi, and M. Arifin. Manajemen Sarana dan Prasarana Sekolah. Yogyakarta: Ar Ruzz Media, 2012.

Daryanto, and Agung Suprihatin. Pengantar Pendidikan Lingkungan Hidup. Cet. I. Yogyakarta: Gava Media, 2013.

Desfandi, Mirza. "Mewujudkan Masyarakat Berkarakter Peduli Lingkungan melalui Program Adiwiyata." Jurnal Sosial Didaktika, 2(2), 2015: 3137.

Hidayatullah, F., and Mudjito. "Implementasi Program Adiwiyata Melalui Kegiatan Lingkungan Berbasis Partisipatif di SMP Negeri 1 Pandaan." Jurnal Inspirasi Manajemen Pendidikan, 5(1), 2017: 1-8.

Muslih, Masnur. Karakter Menjawab Tantangan Krisis Multidimensional. Cet. I. Jakarta: Bumi Aksara, 2011.

Priyanto, Y., M.S. Djati, Soemarno, and Z. Fanan. "Pendidikan Berperspektif Lingkungan Menuju Pembangunan Berkelanjutan." Jurnal Sosial dan Humaniora, 16(1) (41-51), 2013: 41-51.

Setiawan, Agus. Prinsip Pendidikan Karakter dalam Islam (Studi Komparasi Pemikiran al-Ghazali dan Burhanuddin alZarnuji), Dinamika Ilmu, 14 (1), 2014.

Syoffnelli, Zulfan Saam, and Thamrin. "Pengaruh Program Adiwiyata Terhadap Pengetahuan Perilaku dan Keterampilan Siswa dan Guru dalam Mengelola Lingkungan pada SMK di Kabupaten Pelalawan." Jurnal Dinamika Lingkungan Indonesia, 3(1), 2016: 16-23. 
Ummi Nur Rokhmah: Pelaksanaan Program Adiwiyata Sebagai Upaya Pembentukan Karakter Peduli Lingkungan Siswa di Madrasah Ibtidaiyah

Tim Adiwiyata Tingkat Nasional. Paduan Adiwiyata Sekolah Peduli dan Berbudaya Lingkungan. Jakarta: Kerjasama Kementrian Lingkungan Hidup dan Kementrian Kebudayaan dan Pendidikan, 2011.

Tim Teknis Kementrian Lingkungan Hidup RI. Panduan Singkat menjadi Sekolah Adiwiyata. Jakarta: Kementrian Lingkungan Hidup RI, 2012.

Widiyaningrum, P., Lisdiyana, and E. Purwantoyo. "Evaluasi Partisipasi Siswa dalam Pengelolaan Sampah untuk Mendukung Program Sekolah Adiwiyata." Indonesian Journal of Conservation, 4(1), 2015: 74-82. 